FKIP Universitas Kuningan

\title{
PENERAPAN MODEL KARTU BICARA (TIME TOKEN) DALAM PEMBELAJARAN BERBICARA MELAPORKAN PERISTIWA SECARA LISAN PADA SISWA KELAS IX MTS NEGERI 5 KUNINGAN TAHUN AJARAN 2019/2020
}

\author{
SURYAT \\ MTsN 5 Kuningan \\ Jl. Tsanawiyah No. 25 Darma \\ Kabupaten Kuningan, Jawa Barat, Indonesia \\ uyatsuryat51@gmail.com
}

\begin{abstract}
ABSTRAK: Kemampuan berbicara siswa masih minim. Salah satu faktor penyebab minimnya kemampuan berbicara siswa adalah pemanfaatan strategi mengajar. Guru masih mempunyai pemikiran lama sehingga hasil pembelajaran kurang begitu maksimal. Tujuan penelitian ini adalah untuk mendeskripsikan perencanaan model pembelajaran kartu bicara (time token), mendeskripsikan pelaksanaan kegiatan pembelajaran berbicara melaporkan peristiwa, dan mendeskripsikan peningkatan kemampuan berbicara siswa setelah menggunakan model kartu bicara (time token). Metode yang digunakan adalah metode eksperimen dengan desain pretest posttest control group design atau pretest posttest kelompok kontrol.
\end{abstract}

KATA KUNCI: model pembelajaran kartu bicara (time token), berbicara, berbicara melaporkan peristiwa.

\section{THE APPLICATION OF TALK CARD MODEL (TIME TOKEN) IN SPEECH LEARNING IN \\ REPORTING EVENTS ORAL IN CLASS IX STUDENTS OF MTS NEGERI 5 KUNINGAN 2019/2020 Academic Year}

ABSTRACT: Students' speaking ability is still minimal. One of the factors causing the students' lack of speaking ability is the use of teaching strategies. Teachers still have old thoughts so that the learning outcomes are not optimal. The purpose of this study was to describe the planning of the talking card learning model (time token), describe the implementation of learning to speak to report events, and describe the improvement of students' speaking skills after using the talk card model (time token). The method used was an experimental method with pretest posttest control group design or pretest posttest control group.

KEYWORDS: talking card learning model (time token), speaking, speaking to report events.

\begin{tabular}{lccc}
\hline Diterima: & Direvisi: & Distujui: & Dipublikasi: \\
24-09-2020 & - & $01-10-2020$ & $28-10-2020$ \\
Pustaka & Suryat (2020). Penerapan Model Kartu Bicara (Time Token) Dalam Pembelajaran Berbicara \\
& Melaporkan Peristiwa Secara Lisan Pada Siswa Kelas IX MTS Negeri 5 Kuningan Tahun \\
& Ajaran 2019/2020. Fon : Jurnal Pendidikan Bahasa dan Sastra Indonesia, 16(2), 124-133. \\
DOI $\quad:$ https://doi.org/10.25134/fjpbsi.v16i2.3505 & \\
\hline
\end{tabular}

\section{PENDAHULUAN}

Berdasarkan kurikulum yang berlaku pada jenjang SMP/MTs saat ini yaitu Kurikulum 13. Kurikulum ini adalah untuk mempersiapkan manusia Indonesia agar memiliki kemampuan hidup sebagai pribadi dan warga negara yang beriman, produktif, kreatif, inovatif, dan afektif serta mampu berkontribusi pada kehidupan bermasyarakat, berbangsa, bernegara, dan peradaban dunia. (Permen No. 68, 69, dan 70 Tahun 2013).

Mengacu pada Standar Isi Pendidikan dasar dan Menengah yang memuat tentang Tingkat Kompetensi dan Kompetensi Inti sesuai dengan jenjang dan jenis pendidikan tertentu. Kompetensi ini meliputi sikap spiritual, sikap sosial, pengetahuan, dan keterampilan. (Permendikbud No. 21 Tahun 2016). 
Berdasarkan hal di atas, tujuan pembelajaran bahasa adalah membimbing perkembangan bahasa siswa secara berkelanjutan melalui proses mendengarkan, berbicara, membaca, dan menulis. Pada akhirnya tujuan itu adalah untuk membimbing siswa agar mampu menggunakan bahasa untuk belajar, mengekspresikan ide dengan lancar dan jelas, dan berkomunikasi secara efektif dengan dengan orang lain.

Sejalan dengan kondisi di atas, kenyataan di lapangan menunjukkan bahwa perkembangan kemampuan berbahasa para siswa belum mencapai target yang diinginkan. Berdasarkan hasil pengamatan didapatkan bahwa kemampuan berbicara di MTs masih belum mencapai hasil yang diharapkan. Hasil pengamatan awal menunjukkan pembelajaran keterampilan berbicara masih terlihat belum optimal, diantaranya adalah siswa tidak berani tampil di depan kelas, siswa masih malu dalam mengemukakan pendapat, juga siswa belum memiliki rasa percaya diri ketika berbicara di depan kelas.

Model pembelajaran yang hendak peneliti tarapkan dalam penelitian ini adalah model pembelajaran kartu bicara (time token), salah satu model pembelajaran yang diduga dapat mengaktifkan para siswa dalam proses pembelajaran berlangsung. Model pembelajaran kartu bicara (time token) mampu meningkatkan kemampuan para siswa dalam berbicara. Kemampuan yang digali adalah kemampuan berbicara secara perorangan. Dalam pembelajaran ini siswa akan terhindar mendominasi pembicaraan, dan akan terhindar pula siswa diam sama sekali. Dengan demikian model pembelajaran keterampilan berbicara ini siswa akan terlihat aktifitasnya, proses belajar mengajar akan memperoleh hasil yang memuaskan.

Tarigan (2008: 30) menyatakan bahwa Berbicara untuk melaporkan, untuk memberi informasi (informative speaking) dilaksanakan kalau seseorang berkeinginan untuk: (1) memberi atau menanamkan pengetahuan; menetapkan atau menentukan hubunganhubungan antara benda-benda; (3) menerangkan atau menjelaskan suatu proses; dan (4) menginterpretasikan atau menafsirkan sesuatu persetujuan ataupun menguraikan sesuatu tulisan.

$$
\text { Selanjutnya Tarigan }
$$

mengungkapkan pula bahwa pembicaraan-pembicaraan yang bersifat informatif menyandarkan diri pula pada lima sumber utama yaitu : (1) pengalaman-pengalaman yang harus dihubung-hubungkan seperti perjalanan, petualangan, dan cerita roman/novel; (2) proses-proses yang harus dijelaskan, seperti pembuatan sebuah buku, mencampur pigmen-pigmen untuk membuat warna-warna, merekam, serta memotret bunyi; (3) pulisan-tulisan yang harus dijelaskan/dipahami, seperti arti/makna konstitusi, dan Falsafah Plato; (4) ide-ide atau gagasan-gagasan yang harus disingkapkan, seperti makna estetika; (5) instruksi-instruksi atau pengajaran-pengajaran yang harus digambarkan dan diragakan, seperti bagaimana bermain catur, dan bagaimana membuat kapal. (Tarigan, 2008: 30-31). Menurut Berdiati, (2010:59) Model kartu bicara (time token) merupakan salah satu penerapan pembelajaran berbasis masalah cukup efektif untuk meningkatkan keterampilan berbicara siswa secara perorangan. Guru sebagai motivator harus mempunyai energi yang mampu memotivasi siswa mengungkapkan pendapat, saran, dan tanggapan secara aktif, dinamis dan dalam suasana menyenangkan. Dengan kartu bicara yang dimiliki setiap siswa maka siswa mempunyai hak bicara dengan waktu yang ditentukan. Pembelajaran ini juga dapat memotivasi siswa menjadi berani dan percaya diri melatih 
keterampilan berbicaranya. Hal tersebut ditegaskan oleh Hanafiah (2010: 55) pembelajaran kartu bicara (time token) adalah struktur yang dapat digunakan untuk mengajarkan keterampilan sosial, untuk menghindari siswa mendominasi pembicaraan atau siswa diam sama sekali.

Adapun Sintaks model kartu bicara (time token) seperti yang dikemukakan Hanafiah (2010: 55) adalah sebagai berikut: (1) kondisikan kelas untuk melaksanakan diskusi (cooperative learning); (2) setiap siswa diberi kupon berbicaradengan waktu \pm 30 detik; (3) setiap siswa diberi sejumlah nilai sesuai waktu keadaan; (4) jika telah selesai bicara, kupon yang dipegang peserta didik diserahkan, dan setiap berbicara satu kupon; (5) peserta didik yang telah habis kuponnya tidak boleh bicara lagi, dan setiap peserta didik yang masih memegang kupon harus bicara sampai kupunnya habis.

Pernyataan yang sama dilontarkan Suprijono (2011: 133) bahwa langkahlangkah pembelajaran kartu bicara (time token) adalah sebagai berikut: (1) kondisikan kelas untuk melaksanakan diskusi (cooperative learning/CL); (2) tiap siswa diberi kupon berbicara dengan waktu \pm 30 detik. Tiap siswa diberi sejumlah nilai sesuai waktu yang digunakan; (3) bila telah selesai bicara kupon yang dipegang siswa diserahkan. Setiap berbicara satu kupon; (4) siswa yang telah habis kuponnya tak boleh berbicara lagi. Yang masih pegang kupon harus bicara sampai kuponnya habis; (5) dan seterusnya.

Penelitian berkenaan dengan Time

Token rata-rata dilakukan oleh penelitian sebelumnya pada Siswa sekolah dasar untuk kemampuan berbicara seperti penelitaian yang dilakukan oleh Trisnawati (2015). Berjudul Penerapan Model Time Token Berbantuan Audiovisual Untuk Meningkatkakualitas Pembelajaran Ips Siswa Kelas Vc Sdn
Purwoyoso 03 Kota Semarang. Ariyono (2016). berjudul Penerapan Model Cooperative Learning Tipe Time Token Untuk Meningkatkan Hasil Belajar Ips Siswa Kelas Iv Sd Negeri 1 Purwodadi. Dan Fitri (2020) yang barjudul Penerapan Model Pembelajaran Time Token Untuk Meningkatkan Keterampilan Berbicara Siswa Pada Tema Peristiwa Dalam Kehidupan Di Kelas V Mi Al-Hidayah Pekanbaru. Tiga penelitian ini coba dilihat peneliti untuk diterapkan dalam penelitian, namun hasil lain menunjukan penelitian ini lebih cocok untuk mata pelajaran lain seperti penelitian yang dilakukan Nikmah (2013) pada pelajaran Matematika dan Musyayati (2015) dan Warniwati (2019) pada pelajaran IPS menyatakan Time token Cocok untuk peningkatan kemampuan objek penelitian.

Dengan mengacu pada penelitian yang dilakukan oleh Fitri (2020) yang menyatakan dalam penelitiannya bahwa Berdasarkan hasil penelitian, keterampilan berbicara peserta didik pada pelajaran tematik sebelum tindakan hanya mencapai $53,2 \%$ atau berada pada kategori kurang. Setelah dilakukan tindakan keterampilan berbicara pada siklus I meningkat menjadi $60,45 \%$ dengan kategori cukup dan pada siklus II keterampilan berbicara peserta didik kembali meningkat menjadi $83,4 \%$ dengan kategori baik. Maka dapat diambil kesimpulan bahwa penerapan metode pembelajaran time token dapat meningkatkan keterampilan berbicara peserta didik. Peneliti melihat hal tersebut dapat diterapkan di jenjang SLTP atau di MTsN 5 Kuningan.

\section{METODE}

Penelitian ini dilakukan dengan pendekatan kuantitatif dengan metode yang digunakan adalah metode eksperimen dengan desain pretest posttest control group design atau pretest posttest kelompok kontrol. Tujuan penelitian ini adalah untuk mendeskripsikan 
perencanaan model pembelajaran kartu bicara (time token), mendeskripsikan pelaksanaan kegiatan pembelajaran berbicara melaporkan peristiwa, dan mendeskripsikan peningkatan kemampuan berbicara siswa setelah menggunakan model kartu bicara (time token).

Berdasarkan rumusan masalah penelitian, maka tujuan yang hendak dicapai dalam penelitian ini adalah : (1) Mendeskripsikan perencanaan model pembelajaran kartu bicara (time token) di kelas IX MTs Negeri 5 Kuningan Tahun Pelajaran 2019/2020. (2) Mendeskripsikan pelaksanaan kegiatan pembelajaran berbicara melaporkan peristiwa secara lisan dengan model kartu bicara (time token) di kelas IX MTs Negeri 5 Kuningan Tahun Pelajaran 2019/2020. (3) Mendeskripsikan peningkatan kemampuan berbicara siswa kelas IX MTs Negeri 5 Kuningan Tahun Pelajaran 2019/2020 setelah menggunakan model kartu bicara (time token). Adapun pelaksanaan penelitian ini dilakukan mulai dari Pelaksanaan Pembelajaran Berbicara Melaporkan Peristiwa pada kelas eksperimen dengan melihat hasil dan dilanjutkan pada kelas control untuk melihat data yang ada untuk diteliti.

\section{HASIL PENELITIAN}

\section{Data hasil penilaian RPP}

Data yang dapat mendukung dalam penelitian ini adalah Rencana Pelaksanaan Pembelajaran. Hasil penilaian Rencana Pelaksanaan Pembelajaran

Hasil penilaian menunjukkan jumlah skor 67 dengan nilai akhir 4,46. Hal tersebut menggambarkan bahwa nilai pada penyusunan Rencana Pelaksanaan Pembelajaran berada pada rentang nilai 4,01 - 5,00 atau dalam katagori baik sekali.

\section{Pelaksanaan Pembelajaran Berbicara Melaporkan Peristiwa a. Aktivitas Guru}

Pengamatan dilakukan oleh dua observer, yaitu observer pertama adalah peneliti sendiri dan observer kedua adalah teman sejawat yaitu Sdr. Irma Heryani, M.Pd. guru bahas Indonesia pada MTs Negeri 5 Kuningan.

Hasil pengamatan menyatakan jumlah skor yang diperoleh dari semua aspek adalah 64, dengan nilai akhir 4,26. Oleh karena itu, sesuai rentang nilai bahwa aktivitas guru dalam menyampaikan pembelajaran berbicara melaporkan peristiwa secara lisan dengan menggunakan model Kartu Bicara (time token) berada pada rentang 4,01 - 5,00 artinya termasuk pada katagori "baik sekali". Hasil ini sesuai dengan target yang diharapkan.

\section{b. Aktivitas Siswa}

Berikut hasil pengamatan yang dilakukan oleh observer terhadap aktivitas siswa pada pembelajaran berbicara melaporkan peristiwa secara lisan dengan menggunakan model kartu bicara (time token) selama pelaksanaan observasi berlangsung.

Data yang diperoleh menunjukkan bahwa hasil pengamatan terhadap aktivitas siswa jumlah skor yang diperoleh adalah 43, dengan nilai akhir 3,90. Oleh karena itu, aktivitas siswa dalam pembelajaran berbicara melaporkan peristiwa secara lisan dengan menggunakan model Kartu Bicara (time token) berada pada rentang nilai 3,01 4,00 artinya memiliki katagori "baik sekali". Hasil ini sudah sesuai dengan target yang ingin dicapai.

\section{Pelaksanaan Pembelajaran pada Kelas Eksperimen dengan Model Kartu Bicara (Time Token)}

Dari hasil analisis data observasi, mulai dari aktivitas yang dilakukan oleh guru selama proses pembelajaran menunjukkan baik, keseriusan dan keaktifan siswa dalam kegiatanya membuat pembelajaran berjalan lancar. 
Evaluasi model kartu bicara (time token) yang ditunjukkan untuk melihat sejauh mana kemampuan yang dimiliki, terutama dalam keterampilan berbicara melaporkan secara lisan.

\section{Pelaksanaan Pembelajaran pada Kelas Kontrol dengan Model Diskusi Kelas}

Dalam proses pembelajaran terjadi interaksi siswa dalam menyampaikan ideide atau pendapat-pendapatnya secara utuh sesuai dengan tingkat pengetahuan dan penguasaan bahan yang menjadi pokok persoalan di dalam diskusinya. Dalam pembelajaran model diskusi dapat menumbuhkan dan mengembangkan cara berpikir dan bersikap ilmiah. Dengan mengajukan dan mempertahankan pendapatnya dalam diskusi diharapkan para siswa akan dapat memperoleh kepercayaan akan kemampuan diri sendiri. Dengan proses diskusi dapat menunjang usaha-usaha pengembangan pengembangan sikap sosial dan sikap demokratis para siswa.

\section{Hasil Tes}

Data penelitian diambil dari hasil tes kemampuan berbicara siswa melaporkan peristiwa. Data tersebut berupa skor yang diperoleh dari jawaban peserta didik terhadap kemampuan berbicara. Kemampuan berbicara tersebut dapat dilihat dari lima aspek, yaitu tekanan, tata bahasa, kosakata, ketepatan kalimat, dan kelancaran. Data skor untuk setiap pernyataan pada pretes dan postest dari seluruh siswa yang dijadikan objek penelitian. Dalam hal ini, penulis sajikan data pretes dan postest pada kelas ekperimen maupun kelas kontrol.

1) Kelas Eksperimen

\section{Data Hasil Belajar pada Pretest Dan Postes}

Kelas Eksperimen

\begin{tabular}{|c|c|c|c|c|c|c|c|c|c|c|c|c|c|c|c|c|c|c|}
\hline \multirow{2}{*}{$\begin{array}{c}\text { No } \\
\text { Resp. }\end{array}$} & \multicolumn{7}{|c|}{ Pretes } & \multirow{2}{*}{$\begin{array}{l}\text { Total } \\
\text { Skor }\end{array}$} & \multirow{2}{*}{$\begin{array}{l}\text { Rata- } \\
\text { Rata }\end{array}$} & \multicolumn{7}{|c|}{ Postes } & \multirow{2}{*}{$\begin{array}{l}\text { Total } \\
\text { Skor }\end{array}$} & \multirow{2}{*}{$\begin{array}{l}\text { Rata- } \\
\text { Rata }\end{array}$} \\
\hline & 1 & 2 & 3 & 4 & 5 & $\mathrm{Jml}$ & 6 & & & 1 & 2 & 3 & 4 & 5 & $\mathrm{Jml}$ & 6 & & \\
\hline 1 & 2 & 24 & 16 & 6 & 19 & 67 & 60 & 127 & 63.5 & 2 & 24 & 16 & 8 & 23 & 73 & 80 & 153 & 76.5 \\
\hline 2 & 2 & 24 & 12 & 8 & 19 & 65 & 80 & 145 & 72.5 & 2 & 30 & 16 & 10 & 23 & 81 & 100 & 181 & 90.5 \\
\hline 3 & 3 & 18 & 16 & 8 & 15 & 60 & 80 & 140 & 70 & 4 & 30 & 16 & 10 & 19 & 79 & 100 & 179 & 89.5 \\
\hline 4 & 2 & 24 & 16 & 10 & 15 & 67 & 80 & 147 & 73.5 & 2 & 30 & 20 & 10 & 23 & 85 & 100 & 185 & 92.5 \\
\hline 5 & 2 & 24 & 12 & 10 & 15 & 63 & 60 & 123 & 61.5 & 3 & 30 & 16 & 12 & 19 & 80 & 80 & 160 & 80 \\
\hline 6 & 2 & 30 & 16 & 8 & 12 & 68 & 60 & 128 & 64 & 2 & 30 & 20 & 10 & 15 & 77 & 80 & 157 & 78.5 \\
\hline 7 & 2 & 24 & 20 & 6 & 15 & 67 & 80 & 147 & 73.5 & 3 & 30 & 20 & 8 & 19 & 80 & 100 & 180 & 90 \\
\hline 8 & 2 & 24 & 16 & 10 & 12 & 64 & 60 & 124 & 62 & 2 & 24 & 20 & 12 & 15 & 73 & 80 & 153 & 76.5 \\
\hline 9 & 3 & 18 & 16 & 8 & 15 & 60 & 60 & 120 & 60 & 3 & 24 & 20 & 10 & 19 & 76 & 80 & 156 & 78 \\
\hline 10 & 2 & 18 & 16 & 10 & 15 & 61 & 80 & 141 & 70.5 & 3 & 24 & 20 & 12 & 19 & 78 & 100 & 178 & 89 \\
\hline 11 & 2 & 30 & 12 & 8 & 15 & 67 & 60 & 127 & 63.5 & 2 & 30 & 16 & 8 & 19 & 75 & 80 & 155 & 77.5 \\
\hline 12 & 3 & 18 & 16 & 6 & 15 & 58 & 60 & 118 & 59 & 3 & 24 & 20 & 10 & 19 & 76 & 80 & 156 & 78 \\
\hline 13 & 2 & 24 & 16 & 10 & 12 & 64 & 80 & 144 & 72 & 3 & 30 & 20 & 10 & 15 & 78 & 100 & 178 & 89 \\
\hline 14 & 2 & 18 & 12 & 8 & 19 & 59 & 80 & 139 & 69.5 & 2 & 24 & 20 & 10 & 19 & 75 & 100 & 175 & 87.5 \\
\hline 15 & 2 & 18 & 16 & 8 & 19 & 63 & 80 & 143 & 71.5 & 2 & 24 & 20 & 10 & 19 & 75 & 100 & 175 & 87.5 \\
\hline 16 & 2 & 30 & 12 & 8 & 15 & 67 & 60 & 127 & 63.5 & 2 & 30 & 16 & 10 & 19 & 77 & 80 & 157 & 78.5 \\
\hline 17 & 2 & 30 & 12 & 8 & 15 & 67 & 60 & 127 & 63.5 & 2 & 30 & 16 & 10 & 19 & 77 & 80 & 157 & 78.5 \\
\hline 18 & 2 & 24 & 16 & 10 & 12 & 64 & 80 & 144 & 72 & 3 & 30 & 20 & 10 & 15 & 78 & 100 & 178 & 89 \\
\hline 19 & 2 & 18 & 16 & 10 & 15 & 61 & 80 & 141 & 70.5 & 2 & 24 & 20 & 10 & 19 & 75 & 100 & 175 & 87.5 \\
\hline 20 & 2 & 18 & 16 & 8 & 19 & 63 & 60 & 123 & 61.5 & 2 & 30 & 20 & 8 & 19 & 79 & 80 & 159 & 79.5 \\
\hline 21 & 2 & 24 & 12 & 8 & 19 & 65 & 60 & 125 & 62.5 & 3 & 30 & 16 & 10 & 19 & 78 & 80 & 158 & 79 \\
\hline 22 & 3 & 24 & 16 & 6 & 15 & 64 & 80 & 144 & 72 & 3 & 30 & 20 & 8 & 19 & 80 & 100 & 180 & 90 \\
\hline 23 & 2 & 18 & 16 & 8 & 19 & 63 & 80 & 143 & 71.5 & 3 & 24 & 20 & 10 & 19 & 76 & 100 & 176 & 88 \\
\hline 24 & 2 & 24 & 16 & 8 & 19 & 69 & 60 & 129 & 64.5 & 3 & 30 & 20 & 8 & 19 & 80 & 80 & 160 & 80 \\
\hline 25 & 2 & 24 & 16 & 8 & 19 & 69 & 60 & 129 & 64.5 & 2 & 30 & 20 & 10 & 23 & 85 & 80 & 165 & 82.5 \\
\hline 26 & 2 & 18 & 16 & 6 & 15 & 57 & 60 & 117 & 58.5 & 3 & 24 & 20 & 8 & 19 & 74 & 80 & 154 & 77 \\
\hline 27 & 2 & 18 & 16 & 8 & 19 & 63 & 80 & 143 & 71.5 & 3 & 24 & 20 & 10 & 23 & 80 & 100 & 180 & 90 \\
\hline 28 & 2 & 24 & 16 & 8 & 19 & 69 & 80 & 149 & 74.5 & 2 & 30 & 20 & 10 & 19 & 81 & 100 & 181 & 90.5 \\
\hline 29 & 2 & 18 & 16 & 6 & 15 & 57 & 80 & 137 & 68.5 & 3 & 24 & 20 & 8 & 19 & 74 & 100 & 174 & 87 \\
\hline 30 & 2 & 24 & 12 & 10 & 15 & 63 & 60 & 123 & 61.5 & 2 & 30 & 16 & 10 & 19 & 77 & 80 & 157 & 78.5 \\
\hline 31 & 2 & 24 & 16 & 8 & 19 & 69 & 60 & 129 & 64.5 & 2 & 30 & 20 & 10 & 23 & 85 & 80 & 165 & 82.5 \\
\hline 32 & 2 & 18 & 16 & 8 & 19 & 63 & 80 & 143 & 71.5 & 3 & 24 & 20 & 10 & 19 & 76 & 100 & 176 & 88 \\
\hline \multicolumn{6}{|c|}{ Jumlah } & 2046 & 2240 & 4286 & 2143 & & & & & & 2493 & 2880 & 5373 & 2687 \\
\hline \multicolumn{6}{|c|}{ Rata-rata } & 63,94 & 70 & 133.9 & 66.97 & & & & & & 77,91 & 90 & 167.9 & 83.95 \\
\hline
\end{tabular}




\section{Keterangan:}

1. Tekanan

2. Tata bahasa

3. Kosakata
4. Ketepatan kalimat

5. Kelancaran

6. Kebenaran isi
Tingkat Kefasihan Kelas Eksperimen

Data hasil tes kemampuan berbicara kelas eksperimen pada tes awal (pretest) siswa yang memperoleh jumlah skor 53-62 pada tingkat kefasihan 2+ (mampu berbicara untuk memenuhi kebutuhan rutin sosial) sebanyak 8 orang $(25, \%)$, siswa yang memperoleh jumlah skor 63-72 dengan tingkat kefasihan 3 (mampu berbicara dengan cermat akan tetapi pemilihan kosakata sering tidak tepat dan keterbatasan penguasaannya menghambat kelancara komunikasi dalam masalah sosial dan profesional) sebanyak 21 orang $(65,63 \%)$, dan siswa yang memperoleh jumlah skor 73-82 dengan tingkat kefasihan $3+$ (mampu berbicara dengan ketepatan tata bahasa dan kosakata untuk berperan serta dalam umumnya percakapan formal dan nonformal dalam masalah yang bersifat praktis, sosial, dan profesional) sebanyak 3 orang $(9,37 \%)$.
Sementara itu pada tes akhir (postest) menunjukkan siswa yang memperoleh jumlah skor 73-82 dengan tingkat kefasihan $3+$ (mampu berbicara dengan ketepatan tata bahasa dan kosakata untuk berperan serta dalam umumnya percakapan formal dan nonformal dalam masalah yang bersifat praktis, sosial, dan profesional) sebanyak 16 orang $(50 \%)$, dan siswa yang memperoleh jumlah skor 83-92 dengan tingkat kefasihan 4 (mampu memergunakan bahasa itu dengan fasih dan tepat dalam segala tingkat sesuai dengan kebutuhan profesional) sebanyak 16 orang $(50 \%)$. Oleh karena itu secara klasikal telah terjadi peningkatan kemampuan berbicara dari tingkat kefasihan 2+ (mampu berbicara untuk memenuhi kebutuhan rutin sosial) sampai dengan tingkat kefasihan 4 (mampu memergunakan bahasa itu dengan fasih dan tepat dalam segala tingkat sesuai dengan kebutuhan profesional).

2) Kelas Kontrol

Data Hasil Belajar pada Pretes Dan Posttest Kelas Kontrol

\begin{tabular}{|c|c|c|c|c|c|c|c|c|c|c|c|c|c|c|c|c|c|c|}
\hline \multirow{2}{*}{$\begin{array}{c}\text { No } \\
\text { Resp }\end{array}$} & \multicolumn{7}{|c|}{ Pretes } & \multirow{2}{*}{$\begin{array}{l}\text { Total } \\
\text { Skor }\end{array}$} & \multirow{2}{*}{$\begin{array}{l}\text { Rata- } \\
\text { Rata }\end{array}$} & \multicolumn{7}{|c|}{ Postes } & \multirow{2}{*}{$\begin{array}{l}\text { Total } \\
\text { Skor }\end{array}$} & \multirow{2}{*}{$\begin{array}{l}\text { Rata- } \\
\text { Rata }\end{array}$} \\
\hline & 1 & 2 & 3 & 4 & 5 & $\mathrm{Jml}$ & 6 & & & 1 & 2 & 3 & 4 & 5 & $\mathrm{Jml}$ & 6 & & \\
\hline 1 & 2 & 30 & 12 & 8 & 15 & 67 & 60 & 127 & 63.5 & 2 & 30 & 16 & 10 & 19 & 77 & 80 & 157 & $\begin{array}{l}78.5 \\
\end{array}$ \\
\hline 2 & 2 & 18 & 16 & 10 & 15 & 61 & 80 & 141 & 70.5 & 3 & 24 & 20 & 10 & 19 & 76 & 100 & 176 & 88 \\
\hline 3 & 2 & 24 & 16 & 10 & 12 & 64 & 80 & 144 & 72 & 2 & 30 & 20 & 10 & 15 & 77 & 80 & 157 & 78.5 \\
\hline 4 & 2 & 18 & 16 & 8 & 19 & 63 & 60 & 123 & 61.5 & 2 & 24 & 20 & 8 & 19 & 73 & 80 & 153 & 76.5 \\
\hline 5 & 3 & 24 & 16 & 6 & 15 & 64 & 80 & 144 & 72 & 3 & 24 & 16 & 8 & 19 & 70 & 100 & 170 & 85 \\
\hline 6 & 2 & 24 & 12 & 8 & 19 & 65 & 60 & 125 & 62.5 & 3 & 30 & 16 & 8 & 19 & 76 & 80 & 156 & 78 \\
\hline 7 & 2 & 18 & 16 & 8 & 19 & 63 & 80 & 143 & 71.5 & 3 & 24 & 20 & 10 & 19 & 76 & 80 & 156 & 78 \\
\hline 8 & 2 & 24 & 16 & 8 & 19 & 69 & 60 & 129 & 64.5 & 2 & 30 & 20 & 10 & 19 & 81 & 80 & 161 & 80.5 \\
\hline 9 & 2 & 24 & 16 & 8 & 19 & 69 & 80 & 149 & 74.5 & 2 & 30 & 20 & 10 & 19 & 81 & 100 & 181 & 90.5 \\
\hline 10 & 2 & \begin{tabular}{|l|}
18 \\
\end{tabular} & 20 & 6 & 15 & 61 & 60 & 121 & 60.5 & 3 & 24 & 20 & 8 & 19 & 74 & 80 & 154 & 77 \\
\hline 11 & 2 & \begin{tabular}{|l|}
18 \\
\end{tabular} & 16 & 8 & 19 & 63 & 80 & 143 & 71.5 & 3 & 24 & 20 & 10 & 19 & 76 & 100 & 176 & 88 \\
\hline 12 & 2 & 24 & 16 & 8 & 19 & 69 & 80 & 149 & 74.5 & 2 & 30 & 20 & 10 & 19 & 81 & 100 & 181 & 90.5 \\
\hline 13 & 2 & \begin{tabular}{|l|}
18 \\
\end{tabular} & 16 & 6 & 15 & 57 & 80 & 137 & 68.5 & 3 & 24 & 20 & 8 & 19 & 74 & 100 & 174 & 87 \\
\hline
\end{tabular}


FKIP Universitas Kuningan

\begin{tabular}{|c|c|c|c|c|c|c|c|c|c|c|c|c|c|c|c|c|c|c|}
14 & 2 & 24 & 12 & 10 & 15 & 63 & 60 & 123 & 61.5 & 2 & 30 & 16 & 10 & 19 & 77 & 80 & 157 & 78.5 \\
\hline 15 & 2 & 24 & 16 & 8 & 19 & 69 & 60 & 129 & 64.5 & 2 & 30 & 20 & 10 & 19 & 81 & 80 & 161 & 80.5 \\
\hline 16 & 2 & 18 & 16 & 8 & 19 & 63 & 80 & 143 & 71.5 & 3 & 24 & 20 & 10 & 19 & 76 & 80 & 156 & 78 \\
\hline 17 & 2 & 24 & 16 & 6 & 19 & 67 & 60 & 127 & 63.5 & 2 & 30 & 20 & 8 & 19 & 79 & 80 & 159 & 79.5 \\
\hline 18 & 2 & 24 & 12 & 8 & 19 & 65 & 80 & 145 & 72.5 & 2 & 30 & 16 & 8 & 19 & 75 & 100 & 175 & 87.5 \\
\hline 19 & 3 & 18 & 16 & 8 & 15 & 60 & 80 & 140 & 70 & 3 & 24 & 16 & 10 & 19 & 72 & 100 & 172 & 86 \\
\hline 20 & 2 & 24 & 16 & 10 & 15 & 67 & 80 & 147 & 73.5 & 2 & 30 & 20 & 10 & 15 & 77 & 100 & 177 & 88.5 \\
\hline 21 & 2 & 24 & 12 & 10 & 15 & 63 & 60 & 123 & 61.5 & 2 & 30 & 16 & 10 & 19 & 77 & 80 & 157 & 78.5 \\
\hline 22 & 2 & 30 & 16 & 8 & 12 & 68 & 60 & 128 & 64 & 2 & 30 & 20 & 10 & 15 & 77 & 80 & 157 & 78.5 \\
\hline 23 & 2 & 24 & 20 & 6 & 15 & 67 & 80 & 147 & 73.5 & 3 & 30 & 20 & 8 & 19 & 80 & 80 & 160 & 80 \\
\hline 24 & 2 & 24 & 16 & 10 & 12 & 64 & 60 & 124 & 62 & 2 & 30 & 20 & 10 & 15 & 77 & 80 & 157 & 78.5 \\
\hline 25 & 3 & 18 & 16 & 8 & 15 & 60 & 60 & 120 & 60 & 3 & 24 & 20 & 10 & 19 & 76 & 80 & 156 & 78 \\
\hline 26 & 2 & 18 & 16 & 10 & 15 & 61 & 80 & 141 & 70.5 & 3 & 24 & 20 & 10 & 19 & 76 & 100 & 176 & 88 \\
\hline 27 & 2 & 30 & 12 & 8 & 15 & 67 & 60 & 127 & 63.5 & 2 & 30 & 16 & 10 & 19 & 77 & 80 & 157 & 78.5 \\
\hline 28 & 3 & 18 & 16 & 6 & 15 & 58 & 60 & 118 & 59 & 3 & 24 & 20 & 8 & 19 & 74 & 80 & 154 & 77 \\
\hline 29 & 2 & 24 & 16 & 10 & 12 & 64 & 80 & 144 & 72 & 3 & 30 & 20 & 10 & 15 & 78 & 100 & 178 & 89 \\
\hline 30 & 2 & 18 & 12 & 8 & 19 & 59 & 80 & 139 & 69.5 & 3 & 24 & 16 & 10 & 19 & 72 & 80 & 152 & 76 \\
\hline 31 & 2 & 18 & 16 & 8 & 19 & 63 & 80 & 143 & 71.5 & 3 & 24 & 20 & 10 & 19 & 76 & 100 & 176 & 88 \\
\hline \multicolumn{6}{|c|}{ Jumlah } & & 1983 & 2200 & 4183 & 2092 & & & & 2369 & 2720 & 5089 & 2545 \\
\hline & Rata-rata & 63,97 & 71 & 134.9 & 67.47 & & & & 76,42 & 87,74 & 164.2 & 82.08 \\
\hline
\end{tabular}

\section{Keterangan:}

1. Tekanan

2. Tata bahasa

3. Kosakata
4. Ketepatan kalimat

5. Kelancaran

6. Kebenaran isi

\section{Tingkat Kefasihan Kelas Kontrol}

Data hasil tes kemampuan berbicara kelas eksperimen pada tes awal (pretest) siswa yang memperoleh jumlah skor 53-62 pada tingkat kefasihan 2+ (mampu berbicara untuk memenuhi kebutuhan rutin sosial) sebanyak 8 orang $(25, \%)$, siswa yang memperoleh jumlah skor 63-72 dengan tingkat kefasihan 3 (mampu berbicara dengan cermat akan tetapi pemilihan kosakata sering tidak tepat dan keterbatasan penguasaannya menghambat kelancara komunikasi dalam masalah sosial dan profesional) sebanyak 21 orang $(65,63 \%)$, dan siswa yang memperoleh jumlah skor 73-82 dengan tingkat kefasihan $3+$ (mampu berbicara dengan ketepatan tata bahasa dan kosakata untuk berperan serta dalam umumnya percakapan formal dan nonformal dalam masalah yang bersifat praktis, sosial, dan profesional) sebanyak 3 orang $(9,37 \%)$. Sementara itu pada tes akhir (postest) menunjukkan siswa yang memperoleh jumlah skor 73-82 dengan tingkat kefasihan 3+ (mampu berbicara dengan ketepatan tata bahasa dan kosakata untuk berperan serta dalam umumnya percakapan formal dan nonformal dalam masalah yang bersifat praktis, sosial, dan profesional) sebanyak 16 orang $(50 \%)$, dan siswa yang memperoleh jumlah skor 83-92 dengan tingkat kefasihan 4 (татри memergunakan bahasa itu dengan fasih dan tepat dalam segala tingkat sesuai dengan kebutuhan profesional) sebanyak 16 orang $(50 \%)$. Oleh karena itu secara klasikal telah terjadi peningkatan kemampuan berbicara dari tingkat kefasihan 2+ (mampu berbicara untuk memenuhi kebutuhan rutin sosial) sampai dengan tingkat kefasihan 4 (mampu memergunakan bahasa itu dengan fasih dan tepat dalam segala tingkat sesuai dengan kebutuhan profesional).

\section{Tingkat Kebenaran Isi}

Berdasarkan data yang diperoleh dalam penelitian, Komponen kebenaran 
isi kemampuan berbicara kelas kontrol pada pretest bahwa siswa yang memperoleh nilai 60 sebanyak 14 orang $(45,16 \%)$ dengan jumlah nilai 840 , dan siswa yang memperoleh nilai 80 sebanyak 17 orang $(54,83 \%)$ dengan jumlah nilai 1360. Jumlah total nilai siswa seluruh kelas 2200, dengan rata-rata 70,96. Sedangkan pada postest siswa yang memperoleh nilai 80 sebanyak 19 orang $(61,29 \%)$ dengan jumlah nilai 1520 , dan siswa yang memperoleh nilai 100 sebanyak 12 orang $(38,70 \%)$ dengan jumlah nilai 1200 . Jumlah total nilai siswa seluruh kelas 2720 , dengan nilai rata-rata 87,74. Oleh karena itu komponen kebenaran isi mengalami peningkatan nilai rata-rata dari 70,96 (dalam pterest) menjadi 87,74 (dalam posttest).

Sementara itu kemampuan berbicara kelas eksperimen pada pretest bahwa siswa yang memperoleh nilai 60 sebanyak 16 orang $(50 \%)$ dengan jumlah nilai 960, dan siswa yang memperoleh nilai 80 sebanyak 16 orang $(50 \%)$ dengan jumlah nilai 1280 . Jumlah total nilai siswa seluruh kelas 2240, dengan rata-rata 70,00. Sedangkan pada postest siswa yang memperoleh nilai 80 sebanyak 16 orang $(50 \%)$ dengan jumlah nilai 1280 , dan siswa yang memperoleh nilai 100 sebanyak 16 orang $(50 \%)$ dengan jumlah nilai 1600 . Jumlah total nilai siswa seluruh kelas 2880 , dengan nilai rata-rata 90,00. Oleh karena itu komponen kebenaran isi mengalami peningkatan nilai rata-rata dari 70,00 (dalam pterest) menjadi 90,00 (dalam posttest).

Bardasarkan uraian di atas maka dapat dipastikan bahwa nilai siswa tentang kebenaran isi pada postest kelas eksperimen lebih besar dibanding dengan nilai postest pada kelas kontrol, yakni $90,00>87,74$.

\section{KESIMPULAN}

Berdasarkan hasil analisis data dan pembahasan penelitian ini dapat ditarik beberapa kesimpulan: a. Rencana Pelaksanaan Pembelajaran (RPP) yang diterapkan di kelas eksperimen dinyatakan "baik sekali" dengan nilai akhir 4,46. Hal tersebut ditunjukkan dengan komponenkomponen RPP dari mulai kegiatan awal, inti, dan penutup sudah mengarah pada perencanaan yang bisa membuat hasil pembelajaran yang optimal.

b. Aktivitas guru dan siswa dalam pembelajaran berbicara melaporkan peristiwa secara lisan dengan menggunakan model kartu bicara (time token) dinyatakan "baik sekali". Guru dalam pembelajaran sudah melaksanakan tahapan-tahapan kegiatan pembelajaran sesuai perencanaan yang dirancang sebelumnya, sehingga proses pembelajaran sesuai dengan rencana. Data menunjukkan perolehan nilai berdasarkan hasil pengamatan terhadap aktivitas guru dalam proses pembelajaran mendapat skor 64 dengan nilai akhir 4,26 artinya aktivitas guru dinyatakn "baik sekali". Begitu pula siswa dalam mengikuti pembelajaran sudah menunjukkan aktivitas sesuai dengan rencana. Berdasarkan data hasil observasi aktivitas siswa memperoleh skor 43 dengan nilai akhir 3,90 artinya aktivitas siswa dalam pembelajaran "baik sekali"

c. Model kartu bicara (time token) dapat meningkatkan kemampuan berbicara siswa dalam melaporkan peristiwa secara lisan. Hal ini terbukti dengan adanya peningkatan nilai kelas eksperimen dalam pretes mendapat rata-rata 66,97 dan dalam postes mendapat rata-rata 83,95. Sementara itu pada kelas kontrol pretes mendapat rata-rata nilai 67,47 dan postes 82,08 . Dari perolehan nilai tersebut ternyata rata-rata postes kelas eksperimen $(83,95)$ lebih besar dari rata-rata postes kelas kontrol $(82,08)$. Di samping itu hasil pengujian hipotesis diperoleh 
$t_{\text {hitung }}$ sebesar 2,423, sedangkan nilai signifikansi sebesar $0,022<\mathrm{p}(0,05)$, maka hipotesis diterima.

Berdasarkan kesimpulan tersebut ada beberapa saran yang perlu disampaikan dalam upaya meningkatkan kemampuan siswa dalam berbicara laporan peristiwa secara lisan, yaitu:

1. Dari RPP yang sudah ada seperti yang diterapkan pada model kartu bicara (time token) dalam pembelajaran berbicara melaporkan peristiwa, harus lebih dikembangkan lagi supaya hasil proses pembelajaran lebih masimal lagi, sehingga model pembelajaran yang dituangkan ke dalam RPP tersebut merupakan alternatif model RPP yang bisa diterapkan oleh para guru.

2. Aktivitas guru dan siswa dalam pembelajaran model kartu bicara (time token) yang dinyatakan "baik sekali" itu jangan terjadi hanya sesaat, namun harus terjadi pada setiap pelaksanaan pembelajaran. Hal ini guru dituntut aktif dan profesional dalam mengelola pembelajaran.

3. Peningkatan kemampuan berbicara yang terjadi dalam pembelajara berbicara melaporkan peristiwa secara lisan dengan model kartu bicara (time token) harus semakin ditingkatkan lagi sehingga dengan perolehan nilai dari pretes ke postes mengalami peningkatan secara signifikan, maka model tersebut sangat ampuh terhadap hasil pembelajaran.

\section{DAFTAR PUSTAKA}

Arifin, Zainal. (2009). Evaluasi Intruksional Prinsip dan Prosedur. Bandung: CV. Karya.

Arikunto, Suharsimi. (2002). Dasar-dasar Evaluasi Pendidikan. Jakarta: Bumi Aksara.
Arikunto, Suharsimi. (2006). Prosedur Penelitian: Suatu Pendekatan Praktik. Jakarta: Rineka Cipta.

ARIYONO, P. (2016). PENERAPAN MODEL COOPERATIVE LEARNING TIPE TIME TOKEN UNTUK MENINGKATKAN HASIL BELAJAR IPS SISWA KELAS IV SD NEGERI 1 PURWODADI.

Arsjad, Maidar G., Mukti U.S. (1988). Pembinaan Kemampuan Berbicara Bahasa Indonesia. Jakarta: Erlangga.

Berdiati, Ika. (2010). Pembelajaran Bahasa Indonesia berbasis Pakem. Bandung: Sega Arsy.

Fitri, I. H. (2020). PENERAPAN MODEL PEMBELAJARAN TIME TOKEN UNTUK MENINGKATKAN KETERAMPILAN BERBICARA SISWA PADA TEMA PERISTIWA DALAM KEHIDUPAN DI KELAS V MI AL-HIDAYAH PEKANBARU (Doctoral dissertation, UNIVERSITAS ISLAM NEGERI SULTAN SYARIF KASIM RIAU).

Hamalik, Oemar. (2009). Proses Belajar Mengajar. Jakarta: Bumi Aksara.

Hanafiah, Nanang., Cucu Suhana. (2010). Konsep Strategi Pembelajaran. Bandung: Rafika Aditama.

Hidayat, Kosadi. Dkk. (1994). Evaluasi Pendidikan dan Penerapan dalam Pengajaran Bahasa Indonesia. Bandung: Alfabeta.

Ibrahim, dkk. (2009). Pembelajaran Kooperatif. Surabaya: UNESA.

Kasbolah. Kasihani (1999). Penelitian Tindakan Kelas. Depdikbud Dirjen Dikti Proyek Pendidikan Guru Sekolah Dasar (Primary School Teacher Development Project). IBRD: LOAN-IND

Kusmana, Suherli. (2012). Guru Bahasa Indonesia Profesional. Jakarta: Multi Kreasi Satudelapan. 
Musyayati, S. (2015). PENINGKATAN KUALITAS PEMBELAJARAN IPS MELALUI TIME TOKEN BERBASIS FLASHCARD PADA SISWA KELAS IIIB SD HJ. ISRIATI BAITURRAHMAN 1 KOTA SEMARANG (Doctoral dissertation, UNIVERSITAS NEGERI SEMARANG).

NIKMAH, U. (2013). Penerapan Teknik Time Token dalam Pembelajaran Kooperatif untuk Meningkatkan Aktivitas Belajar Matematika Siswa Kelas VII MTs Al-Muttaqin Pekanbaru (Doctoral dissertation, UNIVERSITAS ISLAM NEGERI SULTAN SYARIF KASIM RIAU).

Nurgana, 1993. Statistika Penelitian. Bandung: CV. Permadi.

Nurgiyantoro, Burhan. (2010). Penilaian Pembelajaran Bahasa. Yogyakarta: BPFE-YOGYAKARTA.

Pusat Bahasa Departemen Pendidikan Nasional. (2008). Kamus Bahasa Indonesia. Jakarta: Pusat Bahasa.

Riduwan. (2006). Dasar-dasar Statistika. Bandung: Alfabeta.

Sagala, Syaeful. (2011). Konsep dan Makna Pembelajaran. Bandung: Alfabeta.

Stuart, Cristina. (1992). Berbicara Efektif. Jakarta: Institut PPM dan PT. Pustaka Binaman Pressindo.

Sudjana. (1989). Metode Statistika. Bandung: Tarsito.

Sudjana. (2002). Dasar-Dasar Proses Belajar Mengajar. Bandung: Sinar Baru.

Sudjana. (2005). Metode Statistika. Bandung: Tarsito.

Sugiyono. (2002). Dasar-dasar Penelitian Ilmiah. Bandung: Pustaka Setia
Sugiyono. (2010). Metode Penelitian Pendidikan, Pendekatan Kuantitatif, kualitatif dan $R \& D$. Bandung: Alfabeta.

Sugiyono. (2011). Metode Penelitian Pendidikan Pendekata, Kuantitatif, Kualitatif, dan R\&D. Bandung: Alfabeta.

Suprijono, Agus. (2011). Cooperative Learning (teori dan aplikasi PAIKEM). Yogyakarta: Pustaka Pelajar.

Tarigan, Henry Guntur. (2008). Berbicara Sebagai Suatu Keterampilan Berbahasa. Bandung: Angkasa.

Trianto. (2011). Mendesain Model Pembelajaran Inovatif-Progresif. Jakarta: Kencana.

Trisnawati, I. Y. (2015). PENERAPAN MODEL TIME TOKEN BERBANTUAN AUDIOVISUAL UNTUK MENINGKATKAKUALITAS PEMBELAJARAN IPS SISWA KELAS VC SDN PURWOYOSO 03 KOTA SEMARANG (Doctoral dissertation, UNIVERSITAS NEGERI SEMARANG).

Uno, Hamzah B. (2009). Model Pembelajaran Menciptakan Proses Belajar Mengajar yang Kreatif dan Efektif. Jakarta: Bumi Aksara.

Usman, Moh. Uzer. (2001). Menjadi Guru Profesional. Bandung: Rosdakarya.

Warniwati, W. (2019). Pengaruh model pembelajaran time token terhadap hasil belajar siswa kelas VIII pada mata pelajaran IPS Terpadu di MTs Islahul Ummah NW Tibu Jorong Lombok Timur Tahun Pelajaran 2017/2018 (Doctoral dissertation, Universitas Islam Negeri Mataram) 